\title{
"The Parish of St Precarius" and the View of the Social Teaching of the Church
} Jindřich Šrajer, Roman Míčka

\section{Introduction}

Geert van Istendael's essay begins with a question regarding the knowledge of St Precarius' parish. This is in itself a challenging metaphor, heralding a sharp and thought-provoking critique of economic practice, or more precisely of economic rationality, which rules the world, or at least has the ambition to rule the globalised world with dogmatic firmness. Istendael criticised several European institutions: the European Commission, the European Central Bank, the Council of the European Union and, outside of Europe, also the International Monetary Fund. In his opinion, these institutions have been using the recent financial and economic crisis to subvert the foundations of European civilisation, welfare statehood and democracy. In Istendael's view they are guilty especially of not preventing irresponsible speculations in the financial markets, that is, of speculators who know nothing but the power of money. However, none of those are responsible for the 'desolation' of human misery they leave behind, due to the 'untouchable' principle of 'sacred' economic rationality. They take the unfortunate consequences as an occupational hazard. They make their purchases using the money of those who are vulnerable and disadvantaged by this system. According to Istendael, "the economy promoted by the European Commission, European Central bank and others kills hope."1 This especially concerns young people who become frustrated, lose hope regarding work, livelihood, and as a result also hope for the future.

Istendael's statements, i.e., his evaluation of the economic situation, are in many respects similar to those with which Pope Francis has been 'astonishing' the world. In his first Apostolic Exhortation Evangelii Gaudium (2013) he strongly criticised the above mentioned economic rationality which has lost regard for human beings and their dignity. It is characterised by the rule of money, the absolutism of profit. The Pope wrote about an economy of "exclusion" and "inequality", 2 about "idolatry of money and dictatorship of an impersonal economy lacking a truly human purpose". ${ }^{3}$ He talked about an economy which kills. He sees the root of the financial crisis in a profound anthropological crisis, in "the denial of the primacy of the human person". ${ }^{4}$ According to the Pope, a "'throw away' culture" is being promoted, where the "excluded are not the 'exploited' but the outcast, the 'leftovers'". ${ }^{5}$

Although the two authors accord in opinions, they differ noticeably in their premises, which lends a different 'brand' to their analyses. Geert van Istendael, the socially and politically engaged Belgian philosopher, sociologist and intellectual, freely expresses his convictions for which he can be classified as 'leftist' by those who focus on the right-left separation of the political spectrum. The accuracy of this classification may be a matter of passionate and never ending debates. For the Pope, however, such classification is inappropriate. If he interprets the contemporary problems of socio-economic reality in a contemporary way, he does so as a con-

1 Geert van ISTENDAEL, De parochie van Sint-Precarius, Amsterdam: Bert Bakker, 2013, p. 11.

2 Evangelii Gaudium, art. 53.

3 Ibid., art. 55.

4 Ibid., art. 53-55.

5 Ibid., art. 53. 
tinuation of the traditional fundamental position of the social teaching of the Church, which is neutral with respect to the above mentioned classification. He does not defend the interests of one social group against another (employees versus employers). He does not urge the mutually malignant (class) struggle, etc. He only identifies the extremities and imbalances of the present, appealing to the principle of justice. In doing this his focus is on the poor, in the spirit of the Scriptural tradition and the Gospel.

It will therefore surely be interesting to contrast Istendael's emphasis on the welfare state, solidarity and rejection of the contemporary dominant economic rationality on the one hand with the position of the social teaching of the Catholic Church on the other. This should, among others, facilitate a 'healthy' view of the socio-economic reality without ideological preconceptions and the specific agenda of social groups. On the other hand, it cannot be a detailed, full analysis of this reality. As they themselves admit, neither the Pope nor the Church have a privilege to interpreting and solving contemporary problems. ${ }^{6}$ The Pope's and the Church's approach rather aims to urge everyone to vigilance, to analysing the signs of the times, and to accepting responsibility for situations which could, if incorrectly solved, set off dehumanising processes which are difficult to reverse. ${ }^{7}$ So this is especially a reminder of the fact that the issue of poverty and injustice in contemporary society is a matter of both individual and social responsibility, which demands both personal involvement and institutional solutions to problems that have occurred. But first let us attempt to shed light on the essence of Catholic social teaching.

\section{What is Catholic social teaching?}

Catholic social teaching (CST), also known as social teaching of the Church, is a tradition of ecclesiastic documents commenting on contemporary political, economic and social issues. It is a relatively long and wide-reaching tradition of documents. Its core is constituted by the collection of papal social encyclicals, beginning with Pope Leo XIII's encyclical Rerum Novarum (1891) up to the latest encyclical Caritas in Veritate by Benedict XVI (2009). Besides the social encyclicals, other key texts for CST are the Pastoral Constitution on the Church in the Modern World Gaudium et Spes (1965) and the systematised document Compendium of the Social Doctrine of the Church (2004), edited by the Papal Council Iustitia et Pax, which is sometimes informally called the 'social catechism'. ${ }^{8}$ Many other documents reflecting on and evaluating social reality may be included in a broader conception of CST: various papal letters, speeches and messages, apostolic exhortations, documents of several ecclesiastic offices, institutions and local church authorities. ${ }^{9}$ Another example may be the above mentioned apostolic exhortation by Pope Francis, Evangelii Gaudium (2013) about preaching the Gospel in the contemporary world which, though it is not systematically conceived as a social encyclical, within its context and focus comments on some specific serious phenomena of the political, economic and social reality.

CST is not a political program or a specific set of instruction for doing politics. It is 'only' the discipline of moral theology, "an integral part of the Christian conception of life"11 and "part

\footnotetext{
6 Cf. ibid., art. 51, 184.

7 Cf. ibid., art. 51.

8 The Catechism is a collection of the key precepts of the Christian faith, used for catechesis and education.

9 For example, in the Czech context these are the documents of the Czech Conference of Catholic Bishops Pokoj a dobro (2000) and Žeň veřejné diskuse k listu Pokoj a dobro (2002).

10 Cf. Centesimus Annus, art. 55.

11 Mater et Magistra, art. 222.
} 


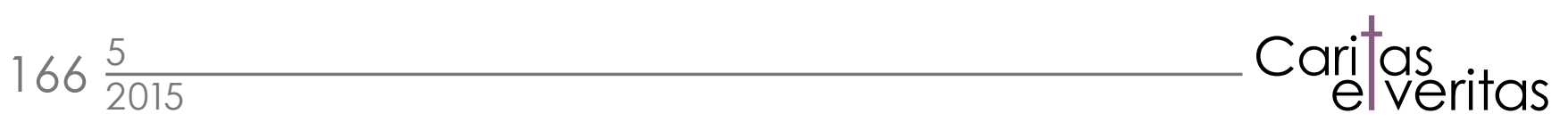

of the Church's evangelizing mission". It expresses "the accurate formulation of the results of a careful reflection on the complex realities of human existence, in society and in the international order, in the light of faith and of the Church's tradition" and it definitely "does not propose economic and political systems or programs, nor does she show preference for one or the other." 12 Undoubtedly, in its core CST expresses fundamental Christian values and truths about man and applies these to social interactions. Thus it "enters into dialogue with the various disciplines concerned with man. It assimilates what these disciplines have to contribute, and helps them to open themselves to a broader horizon, aimed at serving the individual person who is acknowledged and loved in the fullness of his or her vocation." 13 As mentioned above, CST does not claim exclusivity or infallibility in evaluating political and economic realities; it even admits a certain "experiential dimension" 14 and the legitimacy of a multiplicity of views and strategies for realising the values CST stands for. ${ }^{15}$ CST does not aim to partake in the political struggle for the interpretation and organisation of society and its institutions; it considers this struggle to be within the authority of the state and the political sphere. At the same time, it regards itself as striving for justice through "rational argument" and "the promotion of justice through efforts to bring about openness of mind and will to the demands of the common good". ${ }^{16}$

However, such a definition pertains to the Church as an institution. By contrast, individual believers, the laity, should "be aware of their own specific vocation within the political community"17 and directly participate in the formation of political and economic institutions within their own abilities, vocations and roles in society. For them, as well as for people of good will who are willing to listen to the opinions and evaluations of the social teaching of the Church, CST offers "indispensable and ideal orientation", ${ }^{18}$ so both the laity and persons of good will are responsible for finding specific and successful models: "models that are real and truly effective can only arise within the framework of different historical situations, through the efforts of all those who responsibly confront concrete problems in all their social, economic, political and cultural aspects, as these interact with one another" ${ }^{\prime 19}$ At the same time, caution and moderation are necessary if one were to attempt to "appropriate the Church's authority for his opi-nion." 20

Specific involvement in politics is usually connected with taking sides and belonging to a general ideological position (such as conservative, liberal, or social democratic), supporting a specific view of society and suggesting appropriate institutional arrangements. Although there are frequent attempts to interpret and apply CST through the lens of a specific ideology, none of these ideologies is in fact fully compatible with it. Despite the lack of full compatibility, convergence between CST and generally established ideological streams may be found due to similar notions regarding values, as Stephen M. Krason's analysis ${ }^{21}$ has shown. These primarily include conservatism and classical liberalism (freedom and dignity of the person, transcendental grounding of values), to a lesser extent socialism (solidarity, the state's regulatory role in economy) and new forms of liberalism (social rights, ecological issues).

\footnotetext{
12 All in Sollicitudo rei socialis, art. 41.

13 Centesimus Annus, art. 59.

14 Ibid.

15 Cf. Gaudium et Spes, art. 75; Mater et Magistra, art. 238; Octogesima Adveniens, art. 50.

16 Deus Caritas Est, art. 28.

17 Gaudium et Spes, art. 75.

18 Centesimus Annus, art. 43. Emphasis original.

19 Ibid.

20 Gaudium et Spes, art. 43.

21 Cf. Stephen M. KRASON, Liberalism, Conservatism, and Catholicism: An Evaluation of Contemporary American Political Ideologies in Light of Catholic Social Teaching, USA, KY, New Hope: St. Martin de Porres Lay Dominican Community, 1994.
} 


\section{Social teaching of the Church vs. the globally dominant 'economic rationality'}

The necessary distinctions presented above provide a framework for understanding CST'S specific position within the current debates about contemporary socio-economic reality; this includes CST's potential contribution towards the search for promising solutions. Istendael's sharp criticism of economic rationality creates relatively suitable conditions for this. The purpose is not to reject the classical economic definition of rationality, but rather to "show it the place where it operates with positive consequences, and push it back as soon as it crosses its limits". ${ }^{22}$ Istendael emphasised that the market is a human creation and as such can be changed. According to him, if the financial markets are not to be unethical, it is necessary for all to build a barrier of solidarity, constructed in a balanced and carefully organised way. Those who contribute to this, he suggests, show a serious moral sense of responsibility. ${ }^{23}$ Thus Istendael, like CST, points to the great imbalance caused by the separation of economic activity (with the purpose of creating wealth) from political activity (to which the application of justice through redistribution pertains).$^{24}$

It is certainly necessary to elaborate on the rather general statements of CST mentioned above. First of all it is necessary to point to the deeper context of possible disproportions. As we have said in the introduction, according to CST a deep anthropological crisis is at the root of the financial crisis and the many negative issues of the contemporary socio-economic reality, to which Istendael points as well. While Istendael seemingly aims expectation of positive changes in the current situation as well as criticism at institutions, CST emphasises human dignity. CST urges a change of mentality, a purification of reason, personal involvement and responsibility. It emphasises the personal value of the human being from which it derives the requirement for individual involvement and the appropriate form of institutions. According to the Church, "economic action is not to be regarded as something opposed to society. In and of itself, the market is not, and must not become, the place where the strong subdue the weak. Society does not have to protect itself from the market, as if the development of the latter were ipso facto to entail the death of authentically human relations. [...] the market can be a negative force, not because it is so by nature, but because a certain ideology can make it so. It must be remembered that the market does not exist in the pure state. It is shaped by the cultural configurations which define it and give it direction. Economy and finance, as instruments, can be used badly when those at the helm are motivated by purely selfish ends. Instruments that are good in themselves can thereby be transformed into harmful ones. But it is man's darkened reason that produces these consequences, not the instrument per se. Therefore it is not the instrument that must be called to account, but individuals, their moral conscience and their personal and social responsibility." 25

This position conceals an emphasis on, or requirement for, the integral development of man. From this then follows that "institutions by themselves are not enough, because integral human development is primarily a vocation, and therefore it involves a free assumption of responsibility in solidarity on the part of everyone." ${ }^{26}$ CST continues, "such development requires a transcendent vision of the person, it needs God: without him, development is either denied, or entrusted exclusively to man, who falls into the trap of thinking he can bring about

\footnotetext{
22 Geert van ISTENDAEL, De parochie van Sint-Precarius, p. 37.

23 Ibid., pp. 4, 13.

24 Cf. Caritas in veritate, art. 36.

25 Ibid., art. 36.

26 Ibid., art. 11.
} 


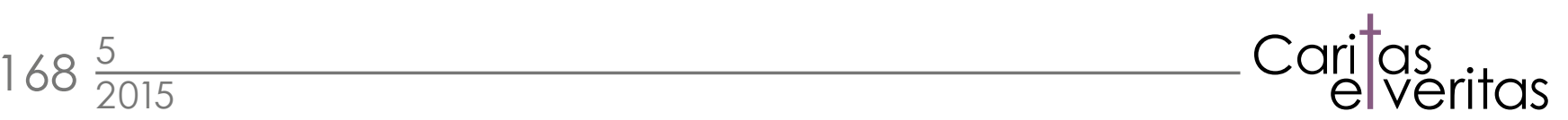

his own salvation, and ends up promoting a dehumanized form of development." ${ }^{27}$ If CST emphasises that integral development of the human being applies to the whole human person in all her dimensions, it ultimately means that " $[\mathrm{w}]$ ithout the perspective of eternal life, human progress in this world is denied breathing-space. Enclosed within history, it runs the risk of being reduced to the mere accumulation of wealth; humanity thus loses the courage to be at the service of higher goods, at the service of the great and disinterested initiatives called forth by universal charity." 28

From what has been said it clearly follows that in CST's understanding contemporary socio-economic problems are not so much economic problems but rather institutional ones, of fundamentally anthropological, ethical, religious and cultural nature. The problem is not in the market and its mechanism but in the human being, who often gives it an 'inhuman form' on local and global level. According to CST, the problem lies especially in preferring theories erroneous in many respects - whose beneficence cannot be empirically confirmed - about the functioning of these mechanisms which disrespect human needs and integral development. CST rejects as dangerous the theory that "everything comes under the laws of competition and survival of the fittest, where the powerful feed upon the powerless". ${ }^{29}$ It rejects the "trickle-down theory" according to which "economic growth, encouraged by a free market, will inevitably succeed in bringing about greater justice and inclusiveness in the world." ${ }^{30}$ In Pope Francis' words, this is "crude and naïve trust in the goodness of those wielding economic power and in the sacralized workings of the prevailing economic system." ${ }^{31}$ He goes on to say that it is (as mentioned above) "economy of exclusion and inequality" and a "selfish ideal" which give rise to the development of "a globalization of indifference". According to the Pope, this is a loss of the ability to experience compassion with the pains and dramas of other people. It is an expression of a lack of interest in care for them, loss of a sense of responsibility. He speaks about the culture of prosperity which in this context deadens the human being. ${ }^{32}$

Istendael, by contrast, seems to speak rather of preserving the achievements of the European welfare state or about its specific recent forms, acceptable for him, rather than about its origins and context. This is precisely what the CST emphasises. It reflects the premises of the welfare state, reminding us that these should serve the integral development of the human being. At the same time the importance of ethics and God is indispensable. According to Pope Francis, it is precisely ethics referring to God what allows for creating an equilibrium and a more humane social order. By contrast, in the deified market transformed into an absolute principle there is no space for a more humane social order, since ethics and God pose a threat and danger to it. Ethics relativize money and power while condemning manipulation and degradation of the human. No one can control or manipulate God. He calls humans to full realisation and independence from any type of slavery. He insists on justice. He expects a serious answer from humans, exceeding the framework of market categories. ${ }^{33}$

Benedict XVI in his encyclical Caritas in Veritate (2009) also states that ethics friendly to the human person is required for the proper functioning of the economy. With respect to practice he made important distinctions. On the one hand he appreciated and supported various activities

\footnotetext{
27 Ibid.

28 Ibid.

29 Evangelii Gaudium, art. 53.

30 Ibid., art. 54.

31 Ibid.

32 Cf. ibid., art. 54.

33 Cf. ibid., art. 56-57.
} 
in this field, such as research centres, courses of business ethics and 'ethical' accounts and financing. On the other hand he called for the establishment of a solid distinguishing criterion to unmask abuse of the attribute 'ethical'. As he said, when "the word is used generically, it can lend itself to any number of interpretations, even to the point where it includes decisions and choices contrary to justice and authentic human welfare." ${ }^{34} \mathrm{He}$ advocated a referential moral system, which he saw precisely in the social teaching of the Church. This is because CST refers to inalienable human dignity based on the human being's likeness to God and accentuates the transcendent value of natural moral norms. In this context, Benedict XVI was convinced that an ethics of economy lacking these two 'pillars' loses moral quality and becomes instrumental. Ethics is in danger of submitting to the existing economic and financial systems, rather than correcting their failures. ${ }^{35}$ According to Pope Benedict XVI, it is ultimately not just necessary to "create 'ethical' sectors or segments of the economy or the world of finance, but to ensure that the whole economy - the whole of finance - is ethical, not merely by virtue of an external label, but by its respect for requirements intrinsic to its very nature." 36

CST's emphasis on the role of ethics with reference to God for creating a human form of socio-economic reality logically implies the question of its universal (global) comprehensibility, or more precisely its enforcement. According to Benedict XVI, the aim of CST in not to impose "on those who do not share the faith ways of thinking and modes of conduct proper to faith. Its aim is simply to help purify reason and to contribute, here and now, to the acknowledgement and attainment of what is just." 37 The Pope does not cease to be convinced of the universality of the Christian faith which, as it is embodied in each culture and at the same time transcends them, "can help them grow in universal brotherhood and solidarity, for the advancement of global and community development." 38 Thus, Benedict XVI calls attention to the danger of the absence of basic faith (in European context this was long held by Christianity), without which everything loses its grounding and measure. Thus humans find themselves on the edge of a cliff in total isolation. Benedict XVI makes an offer to the non-believing world. M. Pera spoke about an offer of respect for the 'lay' God. Such a God is allegedly the God of one's conscience, who turns the human into a morally acting being. ${ }^{39}$ For Pera, there are no significant differences between the 'lay' and Christian God with respect to effects on personal and social life. ${ }^{40}$ In this context, the Pope's words from his social encyclical Deus Caritas Est are important: "Openness to God makes us open towards our brothers and sisters and towards an understanding of life as a joyful task to be accomplished in a spirit of solidarity. On the other hand, ideological rejection of God and an atheism of indifference, oblivious to the Creator and at risk of becoming equally oblivious to human values, constitute some of the chief obstacles to development today. A humanism which excludes God is an inhuman humanism. Only a humanism open to the Absolute can guide us in the promotion and building of forms of social and civic life - structures, institutions, culture and ethos - without exposing us to the risk of becoming ensnared by the fashions of the moment." 41

\footnotetext{
34 Caritas in Veritate, art. 45.

35 Cf. ibid., art. 45.

36 Cf. ibid., art. 45.

37 Deus Caritas Est, art. 28.

38 Caritas in Veritate, art. 59.

39 Pera believes that such a 'lay' God does not have a defined face, incorrigible dogmas, non-revisable revelation, infallible interpreters or special services. He offers humans the opportunity to realise their own finiteness and wretchedness as well as greatness. It is God who mysteriously scolds or praises him. It is the God of his distress and ennoblement. Cf. Marcello PERA, Návrh, který bychom měli přijmout, in: Joseph RATZINGER, Evropa Benedikta z Nurie v krizi kultur, Kostelní Vydř́: Karmelitánské nakladatelství, 2006, p. 19.

40 Cf. Marcello PERA, Návrh, který bychom měli přijmout, pp. 18-19, 40-43.

41 Caritas in Veritate, art. 78.
} 


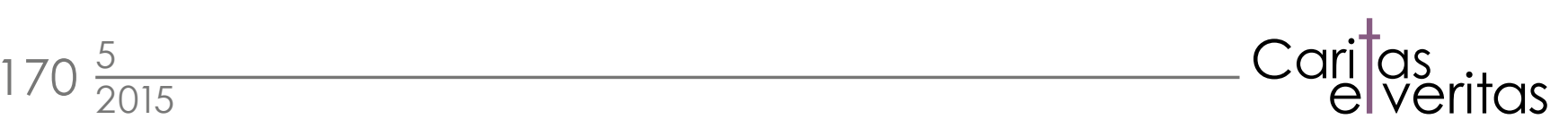

The present Pope Francis has spoken in a spirit similar to that of Benedict XVI. He appealed to responsible politicians "who are genuinely disturbed by the state of society, the people, the lives of the poor." 42 He appealed to governments and financial powers to widen their perspectives and efforts and aim to provide dignified work, health education and care for all citizens. He did not refrain from asking the question: why not turn to God to inspire their plans? ${ }^{43}$ In this way he confirmed the conviction of Benedict XVI to accept the offer made to non-believing laity, which he already formulated as Joseph Cardinal Ratzinger. M. Pera, at the time the President of the Italian Senate, also recommended this, with a distinctive addition: if, thanks to this, we can "lift ourselves up a level higher than where we are now, we can only gain. Everything and everyone: we, our nations, our laws, our Europe and our civilisation itself." ${ }^{4}$ So, according to CST, openness to the transcendent is the necessary foundation enabling the formation of a new political and economic mentality that would help overcome the absolute dichotomy between economic and social, the common good..$^{45}$ Istendael, as we have seen, did not take such a foundation into account, remaining on the surface of the problems he has identified.

\section{The question of the welfare state and solidarity in the global world}

In seriously approaching the issues of purpose, specific form and meaning of the welfare state and solidarity in the global world, we have to bear in mind the difference between CST's and Istendael's criticisms of contemporary socio-economic reality emphasised above.

In its hundred years of history, CST has continually been naming and criticising "'rigid' capitalism" 46 and "radical capitalistic ideology", 47 as well as various deformations and excesses of capitalism (for example the above mentioned elimination of solidarity, the economic approach to man and the risk of financial speculations). Following this tradition, CST calls for the elimination of the symptoms of contemporary bad habits, and especially "heal [...their...] deepest roots." ${ }^{48}$ Istendael strongly supported specific systems of social security preventing masses of people from falling into poverty: systems which were in the past approved in specific European countries and possibly improved by a combination of the best contemporary components included in various systems (regarding unemployment benefits, pensions and medical insurance). CST does not build on such illusory technical solutions. It rather stands for the poor and discriminated while permanently emphasising the adequacy of requirements for life standard and welfare level. It sees the Western world with a kind of critical view: "While the poor of the world continue knocking on the doors of the rich, the world of affluence runs the risk of no longer hearing those knocks, on account of a conscience that can no longer distinguish what is human." 49

Rather than focusing on the specific form of social security, CST concentrates on the basic and indisputable human "right to share in the work which makes wise use of the earth's material resources, and to derive from that work the means to support oneself and one's dependents." 50 CST often calls for solidarity between the rich and the poor and adequate state-organised re-

42 Cf. Evangelii Gaudium, art. 205.

43 Cf. ibid., art. 205.

44 Marcello PERA, Návrh, který bychom měli přijmout, p. 19.

45 Evangelii Gaudium, art. 205.

46 Cf. Laborem Excercens, art. 14.

47 Cf. Centesimus Annus, art. 42.

48 Evangelii Gaudium, art. 205.

49 Caritas in Veritate, art. 75.

50 Centesimus Annus, art. 47. 
distribution in the spirit of social justice. ${ }^{51}$ Solidarity belongs to the fundamental principles of the social teaching of the Church and also among the key aspects of the common good: it "is a firm and persevering determination to commit oneself to the common good; that is to say to the good of all and of each individual, because we are all really responsible for all." 52 In the Church's teaching, the principle of solidarity is balanced out, complemented and corrected by the principle of subsidiarity. Subsidiarity ${ }^{53}$ demands significant human freedom, responsibility and autonomy, being the "expression of inalienable human freedom" ${ }^{54}$ Ignoring subsidiarity entails a "grave evil and disturbance of right order." ${ }^{55}$ Subsidiarity stands in opposition to the paternalistic state, rejecting hypertrophic social politics. CST strongly criticises such trends where the mechanism of solidarity exceeds an adequate level. According to John Paul II, "[b]y intervening directly and depriving society of its responsibility, the Social Assistance State leads to a loss of human energies and an inordinate increase of public agencies, which are dominated more by bureaucratic ways of thinking than by concern for serving their clients, and which are accompanied by an enormous increase in spending." 56 Finally, according to CST, the principle of subsidiarity is "particularly well-suited to managing globalization and directing it towards authentic human development." 57

Istendael's approach to the European welfare state and to the understanding of adequate entitlement to a living standard is, in many respects, based on a somewhat distorted understanding of human rights, which often affects the enactment of rights considered important by CST, as Benedict XVI suggested in the encyclical Caritas in Veritate: "Nowadays we are witnessing a grave inconsistency. On the one hand, appeals are made to alleged rights, arbitrary and non-essential in nature, accompanied by the demand that they be recognized and promoted by public structures, while, on the other hand, elementary and basic rights remain unacknowledged and are violated in much of the world [...] The link consists in this: individual rights, when detached from a framework of duties which grants them their full meaning, can run wild, leading to an escalation of demands which is effectively unlimited and indiscriminate." 58 Such criticism was strengthened and supplemented by the words of Pope Francis. For him, " [s] adly, even human rights can be used as a justification for an inordinate defense of individual rights or the rights of the richer peoples. With due respect for the autonomy and culture of every nation, we must never forget that the planet belongs to all mankind and is meant for all mankind; the mere fact that some people are born in places with fewer resources or less development does not justify the fact that they are living with less dignity. It must be reiterated that 'the more fortunate should renounce some of their rights so as to place their goods more generously at the service of others'. To speak properly of our own rights, we need to broaden our perspective and to hear the plea of other peoples and other regions than those of our own country. We need to grow in a solidarity which 'would allow all peoples to become the artisans of their destiny', since 'every person is called to self-fulfilment'." 59 In this context, it is necessary to approach Istendael's emphasis on "welfare statehood" and its broad defence as an indisputable foundation of the European civilisation and as a "European prime export article" which should become the "model for the whole world" 60 critically.

\footnotetext{
51 Cf., e.g., Quadragesimo Anno, art. 58; Caritas in Veritate, art. 35.

52 Sollicitudo Rei Socialis, art. 38.

53 Cf. Quadragesimo Anno, art. 79.

54 Cf. Caritas in Veritate, art. 75.

55 Quadragesimo Anno, art. 79.

56 Centesimus Annus, art. 48.

57 Caritas in Veritate, art. 57. Cf. also art. 67.

58 Ibid., art. 43.

59 Evangelii Gaudium, art. 190.

60 Geert van ISTENDAEL, De parochie van Sint-Precarius, p. 27.
} 
Although CST has repeatedly strongly criticised 'rough capitalism' and globalisation, it is necessary to keep in mind its wider ideological context holding that globalisation, like the market itself, is not evil per se. Globalisation, "a priori, is neither good nor bad. It will be what people make of it." ${ }^{61}$ Perhaps surprisingly, the encyclical Caritas in Veritate supported in some aspects a further liberalisation of international commerce. ${ }^{62}$ In effect, this necessarily entails the decline of the economic power of rich states, including the risk of a decline in standard of living, which is understood as often hypertrophic, caused by unnatural growth and also the phenomenon of consumerism. ${ }^{63}$ Indeed, this aspect is an important feature of Pope Francis' criticism: he perceived the deformation of the notion of the human being precisely in reducing her to a "consumer"64. However, this more global aspect is not included in Istendael's sole emphasis on the preservation of living standards developed in Europe in the last few decades and "welfare statehood".

There are many points of agreement between Istendael and CST's criticism of socio-economic reality, such as an acute need to solve the structural causes of poverty and the appeal to politicians not to underestimate, or even reject solving these issues. They also concur in rejecting the idea of an egalitarian society and in believing that solving the problems of poverty demands a radical rejection of "the absolute autonomy of markets and financial speculation" together with the removal of the "structural causes of inequality" ${ }^{65}$ However, a significant difference remains between the positions of Istendael and CST, as is clear above. According to CST, "[c] hanging structures without generating new convictions and attitudes will only ensure that those same structures will become, sooner or later, corrupt, oppressive and ineffectual." 66 The difficulties connected with the process of globalisation can only be, according to CST, "overcome if we are able to appropriate the underlying anthropological and ethical spirit that drives globalization towards the humanizing goal of solidarity." 67

\section{CST in relationship to European integration}

Istendael's interesting and notably radical criticism of the European Union should not escape our attention or remain uncompared with CST's positions. He describes contemporary Union elites as "Margaret Thatcher's epigons" and "dogmatic neo-liberals" resolved to ruin the welfare state because they condemn it "with unusual aggression towards the social system". ${ }^{68}$ However, neo-liberals (let us say including Margaret Thatcher) usually understand the direction of the Union's politics (based mostly on the consensus of the leaders of the European People's Party and the Party of European Socialists) as an effort to limit the national sovereignty of member states, connected with problematic interference in free market processes through various regulations. Additionally, the European Union aims to implement its 'European social model' in order to bridge, unify and 'modernise' the differences in social politics and traditions of each state, including anti-discrimination and gender main-streaming agendas which are often criticised from conservative positions. This idea, however, is certainly not neo-liberal.

\footnotetext{
61 John Paul II., Address of the Holy Father to the Pontifical Academy of Social Sciences (27 April 2001), art. 2; Caritas in Veritate, art. 42.

62 Cf. Caritas in Veritate, art. 33, 58.

63 Cf. ibid., art. 58, 61.

64 Cf. Evangelii Gaudium, art. 55.

65 Ibid., art. 202.

66 Ibid., art. 189.

67 Caritas in Veritate, art. 42

68 Cf. Geert van ISTENDAEL, De parochie van Sint-Precarius, pp. 20, 22.
} 
Within various streams of Christian social thinking and Christian-inspired politics, attitudes to European integration vary significantly on a scale from almost unconditional support to radical euro-scepticism. CST does not comment on European integration in its primary documents, though remarks and comments on the process can be found for example in John Paul II's post-synodal apostolic exhortation Ecclesia in Europa (2003). This document emphasised the positive aspects, perspectives and hopes of the integration trend which consist especially in the preservation of peace, development of cooperation between nations, democratic character of changes and economic and political unity. However, it also emphasised the necessary primacy of ethical and spiritual values for the satisfactory and sustainable continuation of the European integration project, together with the decisive contribution of Christianity to the European culture. ${ }^{69}$

Examining different speeches and statements by other Popes, we can notice a change in attitude towards European integration. For example Pius XII was strongly in favour of the project of European integration, supporting the federalist model of Europe applied 'from above', though with a strong role for Catholicism. John Paul II and Benedict XVI were critical of the trends within European integration. In the first place, this was not because of the technical political-economic dimension of integration, but especially regarding the significant uncertainty of its ethical dimension: the democratic deficit, interference in the nation-states' decisions in spheres of family, morality, marriage and protection of unborn life. John Paul II, unlike the previous Popes, ceased to connect the idea of a European culturally-religious identity with the integration project; in general, he was sceptical of such a form of supranational rule. Benedict XVI later radicalised these attitudes, even to the position of a form of Euroscepticism. He predominantly evaluated the EU through an ethical lens, so that European integration became for him an active threat for Christian identity and religious freedom. For example, in his often commented upon address to the Commission of the Bishops' Conferences of the European Community (COMECE) $)^{70}$ in 2007, he suggested that the process of European integration in the current form is evidently not generally shared and is imposed regardless of the citizens. He further pointed out the rejection of important values and the interconnected "unique form of "apostasy'" in Europe, while speaking about a community "built without respect for the true dignity of the human being" and about violating "fundamental human rights". Indeed, Benedict XVI was a strong supporter of expanding the EU to the East, including Turkey, in the hope of revitalising the religious dimension of European identity through the newly accepted countries. However, for these addresses the Pope was criticised even by some Catholic institutions. For example, COMECE itself is a nearly unconditional supporter of European integration, perhaps overlooking its problematic aspects. This fact is noted and thoroughly analysed by, for example, the Czech theoretician of international relations Petr Žák in his articles Josef Ratzinger jako kardinál a papež ve vztahu k evropské integraci [Joseph Ratzinger as Cardinal and Pope in Relationship to European Integration $]^{71}$ and Proměny vztahu papežství k evropské integraci: Od Pia XII. $k$ Benediktu XVI. [Changes of Papal Relationship to European Integration: From Pius XII to Benedict XVI].$^{72}$ For him, one of the causes is a possible difference in representation: while the papacy embodies the Church in her universality, the 'local' European bishops emphasise pragmatic cooperation between the EU and the Church in areas of possible agreement with CST goals. These might include issues of peace, economic cooperation, environmental protection, development and humanitarian aid, and we can also add 'welfare statehood'.

69 Cf. Ecclesia in Europa, esp. art. 19, 108, 109, 110, 114.

70 Cf. Benedict XVI., Address of His Holiness Benedict XVI. to the Participants in the Convention Organized by the Commission of the Bishops' Conferences of the European Community (COMECE), (24. 3. 2007)

71 Petr ŽÁK, Josef Ratzinger jako kardinál a papež ve vztahu k evropské integraci, Církevní dějiny, 11/2013, ISSN 1803-0068, pp. $24-42$. 72 Petr ŽÁK, Proměny vztahu papežství k evropské integraci: Od Pia XII. k Benediktu XVI., Mezinárodní vztahy, 4/2013, ISSN 0323-1844, pp. 67-88. 


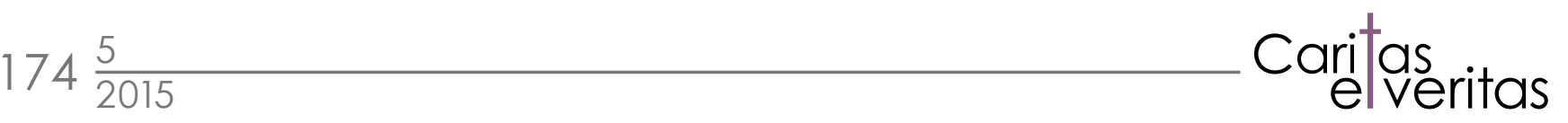

From Pope Francis' statements up until now it is not possible to determine whether the approach to European integration will be modified and developed in some specific way. However, in view of the Pope's prophetic ethos, his uncompromising and open criticism of social defects and his defence of the culture of life, the critical approach regarding the EU is unlikely to change significantly. So far it is apparent that CST emphasises questions of deep moral and anthropological meaning which - in connection with European social and civilisation trends Istendael evidently does not raise.

\section{Social inequality - a threat to peace and democracy}

Now we return to the key idea of Istendael's article, welfare statehood, i.e., to increasing social inequality in the world and masses of people falling into poverty and social dependence. In this context, it is impossible to omit the risks about which both Istendael and CST urgently warn: the threat to basic values, the threat to democracy and peace. According to Istendael, democracy is being replaced by technocracy. ${ }^{73}$ Pope Francis meanwhile points to social inequality as a source of violence and disorder, reminding us that "until exclusion and inequality in society and between peoples are reversed, it will be impossible to eliminate violence. The poor and the poorer peoples are accused of violence, yet without equal opportunities the different forms of aggression and conflict will find a fertile terrain for growth and eventually explode." 74 The following statement of his is becoming grimly prophetic: "When a society - whether local, national or global - is willing to leave a part of itself on the fringes, no political programmes or resources spent on law enforcement or surveillance systems can indefinitely guarantee tranquillity. This is not the case simply because inequality provokes a violent reaction from those excluded from the system, but because the socio-economic system is unjust at its root. Just as goodness tends to spread, the toleration of evil, which is injustice, tends to expand its baneful influence and quietly to undermine any political and social system, no matter how solid it may appear. If every action has its consequences, an evil embedded in the structures of a society has a constant potential for disintegration and death. It is evil crystallized in unjust social structures, which cannot be the basis of hope for a better future. We are far from the so-called 'end of history', since the conditions for a sustainable and peaceful development have not yet been adequately articulated and realized." 75

\section{Conclusion}

Although they differ in their premises, assessments and suggestions for solutions regarding the contemporary socio-economic reality, Istendael's text and CST have the same significance or contribution: arousing the conscience of all people with respect to the needs of others, especially the poorest. They point out that nobody can be "exempt from concern for the poor and for social justice." ${ }^{76}$ CST addresses the need for "healing the deepest roots - and not simply the appearances - of the evils in our world." ${ }^{77}$ It speaks of the need for decisions, programs, mechanism and specific processes focused on better distribution of income, on creating work opportunities and integral support for the poor. ${ }^{78}$

\footnotetext{
73 Geert van ISTENDAEL, De parochie van Sint-Precarius, p. 12-13.

74 Evangelii Gaudium, art. 59.

75 Ibid.

76 Ibid., art. 201.

77 Ibid., art. 205.

78 Cf. ibid., art. 204.
} 
Since CST diagnoses the contemporary bleak socio-economic reality as a result of a deep anthropological crisis, its prospective solutions are also aimed in this direction. Comparing CST with Geert van Instendael's positions in this context then 'convicts' him of a 'naïve' faith in human rationality which should be the foundation of a generally shared solidarity. At the same time he misses the fact that the same rationality is at the root of an 'exploiting' economic reality - often humanly ruthless - which he himself rejects. Although rationality is the foundation for CST as well, this rationality is 'purified' from selfish interests of persons or particular groups. This is achieved by its link to transcendence, God and ethics. This, however, implies to a certain extent a similar suspicion of 'naivety' as in the case of Istendael, because CST assumes something that can never be achieved. By this is meant the human being's and humankind's general openness to the values presented by CST. In other words, it is possible to discuss the insufficient interconnection of the paradigm of the CST with the reality at hand, or more precisely the reality of its applicability and usability. Pope Francis offered a kind of answer to these 'accusations' (or rather doubts) in his discussion of the relationship, or somewhat bipolar tension, between idea and reality. According to him, there "has to be continuous dialogue between the two, lest ideas become detached from realities. It is dangerous to dwell in the realm of words alone, of images and rhetoric." ${ }^{79}$ It holds true that realities are superior to ideas. The following explanation is attached to this: "We have politicians - and even religious leaders who wonder why people do not understand and follow them, since their proposals are so clear and logical. Perhaps it is because they are stuck in the realm of pure ideas and end up reducing politics or faith to rhetoric. Others have left simplicity behind and have imported a rationality foreign to most people." 80

More of the Pope's words attest to the realism of CST, this time in relationship to globalisation. He emphasised the tension between globalisation and localisation, noting the danger of two extremes, of being "an abstract, globalized universe" 81 or becoming "a museum of local folklore, a world apart" 82 . According to the Pope, it is not necessary "to be overly obsessed with limited and particular questions. We must constantly have to broaden our horizons and see the greater good which will benefit us all. But this has to be done without evasion or uprooting. We need to sink our roots deeper into the fertile soil and history of our native place, which is a gift of God." 83

Finally, we can only wish that the Pope's warning, 'prophetic' words regarding the threat of violent reactions causing social inequality and also the silent disintegration of the foundation of all political and social systems caused by the power of evil, that is by injustice, will remain unfulfilled. In this context, CST's appeal for building global solidary humanisation is not only topical, but also acute and therefore unavoidable.

\section{"The Parish of St Precarius" and the View of the Social Teaching of the Church}

Abstract The paper discusses the key theses of the essay De parochie van Sint-Precarius (2013) written by the well-known Belgian author Geert van Istendael. It attempts to analyse the text in it's political and economic context and compares Istendael's ideas and opinions with the views of the Catholic social

\footnotetext{
79 Ibid., art. 231.

80 Ibid., art. 232.

81 Ibid., art. 234.

82 Ibid.

83 Ibid., art. 235.
} 
$176 \frac{5}{2015}$ Caritas elveritas

teaching. The paper concludes that Istandael's text corresponds with CST's diagnosis of the present situation, but there are marked differences in ideological views and suggestions for solving political and economic problems.

Keywords Catholic social teaching; social encyclicals; Geert van Istendael; The Parish of St Precarius; European union; economy, crisis 